
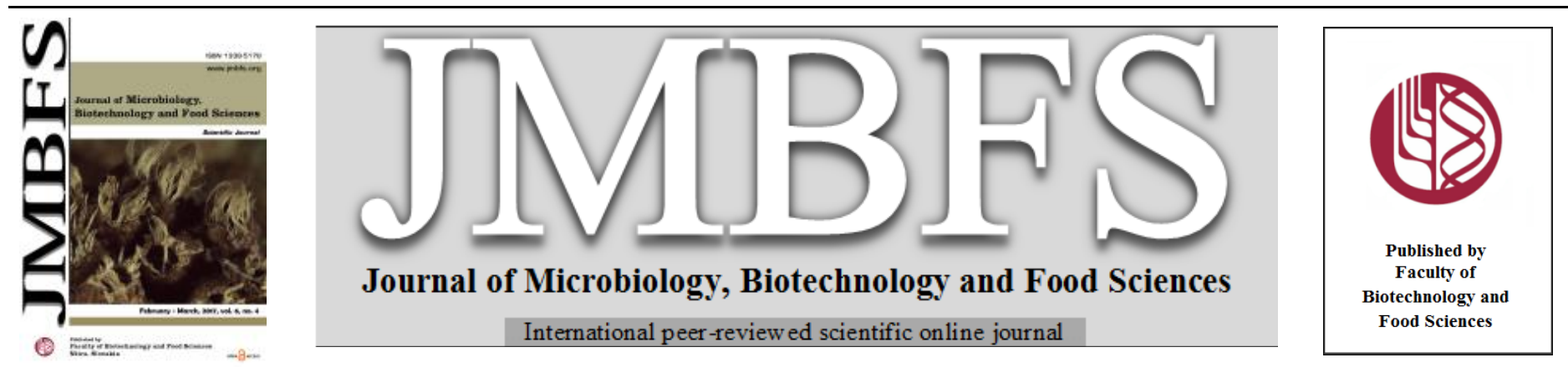

\title{
EFFECT OF LACTIC ACID ON Escherichia coli 0157:H7 AND ON COLOR STABILITY OF VACUUM-PACKAGED BEEF STEAKS UNDER HIGH STORAGE TEMPERATURE
}

\author{
Ana Paula A. A. Salim ${ }^{1,2}$, Anna C. V. C. S. Canto ${ }^{1}$, Bruno R. C. Costa-Lima ${ }^{1}$, Julia S. Simoes ${ }^{1}$, Pedro H. N. Panzenhagen ${ }^{2}$, Robson \\ M. Franco ${ }^{1}$, Teófilo J. P. Silva ${ }^{1}$, Carlos A. Conte-Junior* ${ }^{1,2}$
}

Address(es): Carlos Adam Conte Junior,

${ }^{1}$ Universidade Federal Fluminense (UFF), Faculdade de Veterinaria, Departamento de Tecnologia de Alimentos, Rua Vital Brazil Filho, 64. Postal code 24230-340, Niteroi, Rio de Janeiro, phone number: 2629-9545.

${ }^{2}$ Universidade Federal do Rio de Janeiro (UFRJ), Instituto de Química, Avenida Athos da Silveira Ramos, 149 Bloco A - $7^{\circ}$ andar.

Postal code 21941-909, Rio de Janeiro.

*Corresponding author: carlosconte@id.uff.br

doi: 10.15414/jmbfs.2017.6.4.1054-1058

\section{ARTICLE INFO}

Received 25. 8. 2016

Revised 2. 12. 2016

Accepted 8. 12. 2016

Published 1.2. 2017

Regular article

open $\mathcal{O}_{\text {access }}$

\begin{abstract}
The effect of lactic acid (LA) addition on Escherichia coli O157:H7 survivability as well as the color stability was determined in vacuum-packaged beef steaks storage at $10^{\circ} \mathrm{C}$ for 50 days. Longissimus dorsi muscle was portioned into beef steaks and inoculated with Escherichia coli 0157:H7. Afterwards, the samples were submitted at three treatments: without lactic acid addition or non-treated (NT); with $0.56 \mathrm{M}(5 \%, \mathrm{v} / \mathrm{v})(\mathrm{L} 5)$, and with $1.13 \mathrm{M}(10 \%, \mathrm{v} / \mathrm{v})(\mathrm{L} 10)$ of lactic acid addition. Same division was performed with samples non inoculated. All samples were package at vacuum and stored at $10^{\circ} \mathrm{C}$ during 50 days. L10 demonstrated an efficient bacteriostatic effect $(P<0.05)$ against $E$. coli $\mathrm{O} 157: \mathrm{H} 7$ and total aerobic mesophilic bacteria. Nonetheless, LA induced a decrease $(P<0.05)$ in $a^{*}$ values in samples after application and during storage, promoting discoloration of beef steaks. Therefore, L10 was efficient in controlling E. coli O157:H7 even at abusive storage temperatures. However, this decontamination treatment affects negatively the color stability of beef.
\end{abstract}

Keywords: Food preservation; Organic acid; Longissimus dorsi; Discoloration; EHEC

\section{INTRODUCTION}

Escherichia coli $\mathrm{O} 157: \mathrm{H} 7$ is an important foodborne pathogen, commonly harbored in cattle gut tract (Bell, 2002; Caprioli et al., 2005; Karmali et al., 2010) with high economic impact on industry and public health (Scallan $\boldsymbol{e t}$ al., 2011). Thus, during cattle slaughter and carcass processing there is a considerable risk of fresh cut and processed product cross-contamination with $E$ coli O157:H7 (Barkocy-Gallagher et al., 2003; Huang and Sheen, 2011) corroborating the link between outbreaks of this pathogen and beef (Callaway $\boldsymbol{e t}$ al., 2009; Huang and Sheen, 2011).

In order to control microbial development, the meat industry usually uses organic acids on beef processing (Buncic and Sofos, 2012). Lactic acid (LA) is a weak organic acid generally recognized as safe (GRAS) (FDA, 2016), which is naturally present in the muscle tissue (Siragusa, 1995; Muchenje et al., 2009) and is also produced by fermentative bacteria (Martinez et al., 2013; FDA, 2016). Acid decontamination with LA is considered a simple and valuable chemical strategy to improve food safety in meat products (Ricke, 2003; Skandamis et al., 2010) due to the action immediately after application (Anderson and Marshall, 2007), and also during storage, when the residual LA content exerts bacteriostatic effect on bacterial counts (Dorsa et al., 1998). However, despite LA bacteriological advantages, its application can promote surface color changes on meat (Hunt et al., 1999; Pipek et al., 2005; Hosseini and Esfahani-Mehr, 2015) resulting in economic losses (Smith et al., 2000). Beef color influences the consumer acceptability, which interfere on purchase decisions (Suman et al., 2010). This quality parameter is stated by myoglobin $(\mathrm{Mb})$ redox state on meat: deoxymyoglobin (DMb; purplish-red color), oxymyoglobin ( $\mathrm{OMb}$; bright cherry-red color), and metamyoglobin (MMb; brown color). MMb results from the oxidation of myoglobin (Suman et al., 2007; Suman and Joseph, 2013), and the increase of MMb formation should be avoided in order to prevent the development of brown color on beef products surface. Therefore, it is important the use of package strategies, such as the vacuum package, in order to maintain meat color (Kerry et al., 2006; Zhou et al., 2010), wholesome and safe (Leistner, 2004; John et al., 2005; Han, 2014), during storage.
Previous studies (Youssef et al., 2012; Harris et al., 2012; Youssef et al., 2013; Li et al., 2015; Blagojevic et al., 2015) examined the effect of lactic acid concentrations up to $5 \%$ combined with temperature to evaluate the reduction of E.coli $\mathrm{O} 157: \mathrm{H} 7$ during storage, however, there is a little information about the inhibition effects of use lactic acid concentrations higher than $5 \%$ on vacuum package beef steaks, during prolonged storage at $10^{\circ} \mathrm{C}$. Therefore, the goals of the present research were 1) to evaluate the most efficient lactic acid concentration $(0.56 \mathrm{M} ; 5 \%$, v/v or $1.13 \mathrm{M} ; 10 \%$, v/v) for E. coli $\mathrm{O} 157: \mathrm{H} 7$ reduction and 2) the effect of lactic acid application on $\mathrm{pH}$ and surface color stability of vacuum packaged beef steaks (Longissimus dorsi) during 50 days of storage at $10^{\circ} \mathrm{C}$.

\section{MATERIALS AND METHODS}

Experimental design

Longissimus dorsi (LD) beef $(21 \mathrm{~kg})$ was obtained between the $6^{\text {th }}$ thoracic rib and the $6^{\text {th }}$ lumbar vertebrae from a commercial processing facility inspected by the federal government (Colatina, Espírito Santo Brazil) after $36 \mathrm{~h}$ post-mortem. LD was transported under refrigeration $\left(0^{\circ} \mathrm{C}\right)$ to the Meat Laboratory of Universidade Federal Fluminense where was portioned into beef steaks (100 g each; area: $256 \mathrm{~cm}^{2} ; 9.5 \mathrm{~cm}$ diameter and $2.0 \mathrm{~cm}$ thick approximately). Samples were equally divided in two groups (non-inoculated and inoculated). Both groups were randomly subjected to surface application of LA solution at either $0.56 \mathrm{M}$ $(5 \%, \mathrm{v} / \mathrm{v})(\mathrm{L} 5)$ or $1.13 \mathrm{M}(10 \%, \mathrm{v} / \mathrm{v})(\mathrm{L} 10)$ or were not treated (NT). After LA treatment, samples were vacuum packed and stored for 50 days at $10^{\circ} \mathrm{C}$. The abusive temperature model used to stimulate E. coli $0157: \mathrm{H} 7$ growth was performed follow the indication of Hwang et al. (2014). Three trials $(\mathrm{n}=3 ; 7 \mathrm{~kg}$ each trial) were carried out, totaling 70 unit samples $(100 \mathrm{~g})$ per trial. Physicochemical and bacteriological analyses were performed at days $0,3,15$, 30 , and 50 of storage.

\section{Raw beef inoculation}

Escherichia coli O157:H7 strain (EDL 933) (Gobert et al., 2007) was provided by the Oswaldo Cruz Foundation (Rio de Janeiro, Brazil). The lyophilized 
inoculum was added to brain heart infusion broth (BHI) (Difco ${ }^{\circledR}$, Detroit, MI) and activated at $37^{\circ} \mathrm{C}$ for $24 \mathrm{~h}$. Then, $1 \mathrm{ml}$ aliquots were transferred to test tubes containing $9 \mathrm{ml}$ of $\mathrm{BHI}$, and incubated at $37^{\circ} \mathrm{C}$ for $18 \mathrm{~h}$ (Meng et al., 2001). The inoculum was calculated using an UV spectrophotometer (Smartspec Plus, BioRad, Hercules, CA) at $600 \mathrm{~nm}$ and a concentration of $10^{8}$ cells $/ \mathrm{ml}$ was detected (Lázaro et al., 2014). The inoculum concentration was confirmed by spread plating on Plate Count Agar (PCA) (Merck®, Darmstadt, Germany) and O157:H7 Agar (Merck ${ }^{\circledR}$, Darmstadt, Germany) (Alegre et al., 2010) achieving 6 $\log \mathrm{CFU} / \mathrm{g}$ on meat.

The inoculation was performed on beef steaks $(100 \mathrm{~g})$, aseptically transferred to plastic packages BBL4 (Cryovac $\AA$, Saddle Brook, NJ). In this conditions $0.5 \mathrm{~m}$ of Escherichia coli $0157: \mathrm{H} 7$ inoculum were pipetted on both sides of the beef surfaces (1 $\mathrm{ml}$ per sample) (Alegre $\boldsymbol{e t}$ al., 2010). The inoculated samples were massaged for $1 \mathrm{~min}$ and remained $30 \mathrm{~min}$ at $22{ }^{\circ} \mathrm{C}$ to allow the inoculum attachment to the meat surface (Huang and Chen, 2011; Mahmoud, 2014) After inoculation, the samples were treated with different solutions of lactic acid.

\section{Lactic acid treatment}

Solutions of $0.56 \mathrm{M}(5 \%, \mathrm{v} / \mathrm{v})(\mathrm{L} 5)$ and $1.13 \mathrm{M}(10 \%, \mathrm{v} / \mathrm{v})(\mathrm{L} 10)$ of lactic acid were prepared from $85 \%$ lactic acid (Fisher Scientific, Pittsburgh, PA) using sterile deionized water. Non-inoculated and inoculated LD steaks were pipetted on each side with $2.5 \mathrm{ml}$ of L5 or L10 solutions at room temperature, vacuum sealed, and stored at $10^{\circ} \mathrm{C}$.

\section{Bacteriological evaluation of inoculated beef steaks}

The inoculated steaks $(25 \mathrm{~g})$ were aseptically transferred to sterile bags containing $225 \mathrm{ml}$ of peptone saline $(0.10 \%$ peptone in $0.85 \% \mathrm{NaCl})$ and homogenized utilizing a stomacher (Stomacher 80, Seward Ltd., London, United Kingdom) for $2 \mathrm{~min}$. The homogenized samples were serially diluted in peptone saline and plated onto Petri dishes containing plate count agar (PCA) to evaluate total aerobic mesophilic bacteria (TAMB) (APHA, 2001), and O157:H7 Agar (Merck ${ }^{\circledR}$ KGaA, Darmstadt, Germany) to determine Escherichia coli $\mathrm{O} 157: \mathrm{H} 7$ counts (Alexa et al., 2011). Incubation was performed at $37^{\circ} \mathrm{C}$ for $24 \mathrm{~h}$ and results were expressed as $\log \mathrm{CFU} / \mathrm{g}$.

\section{Physicochemical evaluation of non-inoculated beef steaks}

Non-inoculated steaks (NT, L5 and L10) were used to evaluate $\mathrm{pH}$ values and instrumental color parameters. The analysis of $\mathrm{pH}$ was performed using a Handylab 1 (SchottGlaswerke, Mainz, Germany) $\mathrm{pH}$ meter previously calibrated with buffer solutions at $\mathrm{pH} 4.0$ and 7.0 (AOAC, 2012).

Instrumental color parameters were evaluated using a Minolta CM-600d spectrophotometer (Konica Minolta Sensing Inc., Osaka, Japan) with $8 \mathrm{~mm}$ diameter measuring aperture, illuminant A, and $10^{\circ}$ standard observer (Canto et al., 2015). Meat color was measured at the surface of non-inoculated steaks (NT, $\mathrm{L} 5$, and L10) after blooming for $10 \mathrm{~min}$ at $22^{\circ} \mathrm{C}$. The parameters determined were: lightness ( $L^{*}$ value), redness ( $a^{*}$ value), yellowness ( $b^{*}$ value), and ratio of reflectance 630 to $580 \mathrm{~nm}(\mathrm{R} 630 / 580)$ (AMSA, 2012).

\section{Statistical analysis}

A one-way analysis of variance was performed to evaluate the effect of LA application, LA concentration and days of storage on LD steaks on bacteriological (inoculated) and physicochemical (non-inoculated) parameters using XLSTAT statistical software (Version 2014.5.03, Addinsoft, Inc. Brooklyn, NY, USA). Differences among means were tested using Tukey's test with $95 \%$ of confidence level.

\section{RESULTS}

Regarding the bacteriological evaluation, the inoculated LD steaks treated with LA solutions (L5 and L10) did not exhibit difference $(P>0.05)$ on Escherichic coli $\mathrm{O} 157: \mathrm{H} 7$ and total aerobic mesophilic bacteria (TAMB) counts when compared to non-treated (NT) samples on day 0 of storage (Table 1). However, from day 3 until day 50 of storage, group $\mathrm{L} 10$ showed a significant reduction $(P$ $<0.05$ ) of E. coli $\mathrm{O} 157: \mathrm{H} 7$ and TAMB counts compared to NT, suggesting the bacteriostatic effect of LA, even under abusive temperature.

Table 1 Escherichia coli $\mathrm{O} 157: \mathrm{H} 7$ and total aerobic mesophilic bacteria (TAMB) counts (log cfu/g) on Longissimus dorsi steaks treated with lactic acid storage at $10^{\circ} \mathrm{C}$ during 50 days.

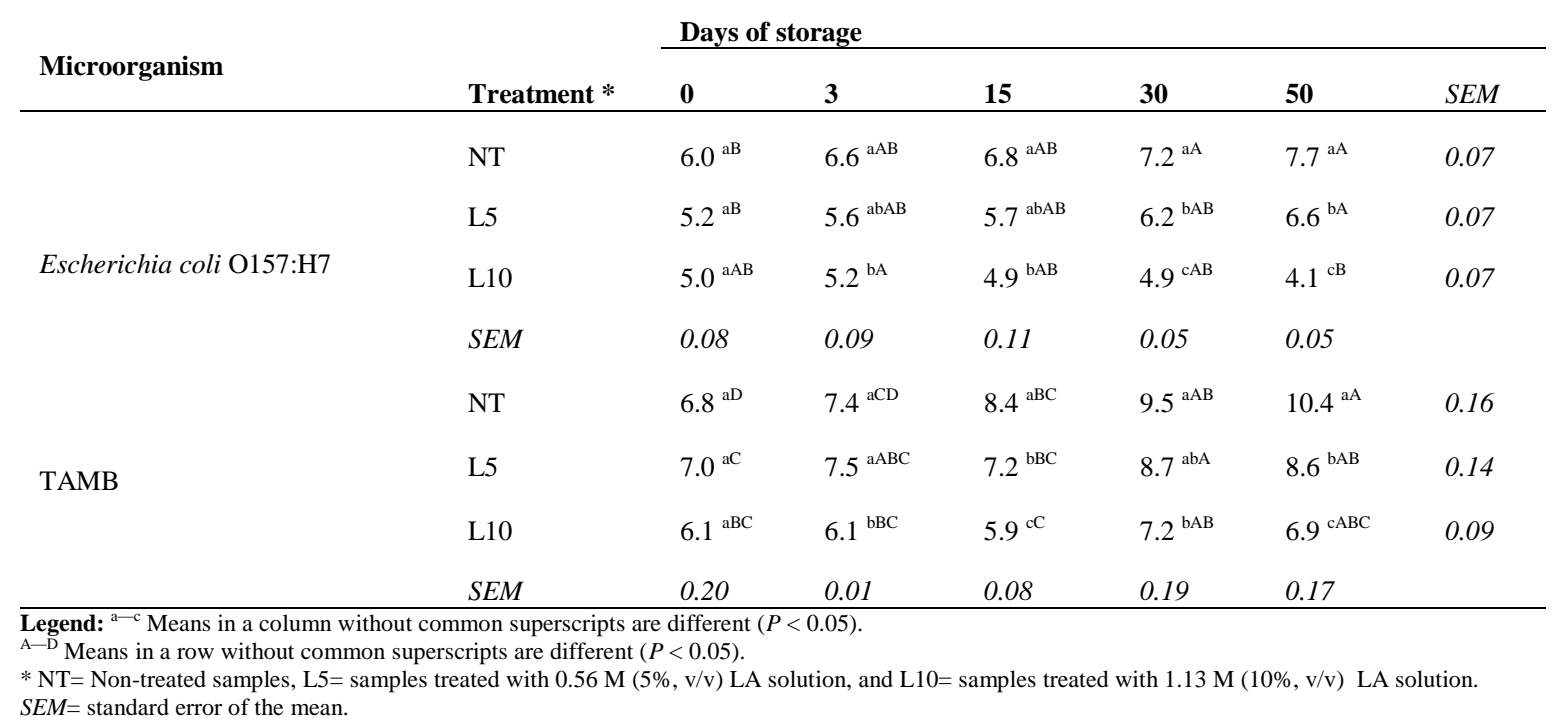

Lactic acid treatment decreased $(P<0.05) \mathrm{pH}$ values (Table 2$)$. In terms of LA concentration on days 0 and 15 , NT exhibited the greatest $(P<0.05) \mathrm{pH}$ values, followed by L5, and L10 which presented the lowest $(P<0.05)$ ones. On the other hand, on days 30 and 50 no difference $(P>0.05)$ was observed between $\mathrm{pH}$ values of L5 and L10. In addition, NT, L5, and L10 exhibited an increase $(P<$ 0.05 ) pattern of $\mathrm{pH}$, during the storage period.

Table 2 shows the instrumental color parameters. LA did not exhibit an immediate effect $(P>0.05)$ on $L^{*}$ values. From day 15 to $50, \mathrm{~L} 10$ decreased $(P<$ $0.05)$ sample lightness while L5 remained similar $(P>0.05)$ to NT samples. In addition, during storage L5 and L10 exhibited $L^{*}$ value decrease $(P<0.05)$ whereas, NT samples did not exhibit $(P>0.05)$ variation. Regarding meat redness (Table 2), LA concentration affected $(P<0.05) a^{*}$ values. NT demonstrated the greatest $(P<0.05) a^{*}$ values, L5 intermediate, and L10 the lowest ones $(P<0.05)$ indicating a concentration-dependent pattern. From day 0 to 50, $a^{*}$ values of L5 and L10 LD steaks decreased $(P<0.05)$, although NT samples did not demonstrated $(P>0.05)$ variation on redness during storage. In terms of yellowness (Table 2$)$, LA treatment promoted an increase $(P<0.05)$ of $b^{*}$ values after application, whereas on days 15, 30 and 50, L10 exhibited the lowest $(P<0.05) b^{*}$ values and no difference $(P>0.05)$ was observed on NT and L5 samples.

Regarding LD steak surface color stability (Table 2), LA concentration and storage period affected $(P<0.05)$ R630/580 values. During all storage days, NT exhibited the greatest $(P<0.05)$ R630/580 values. At days 0 and 15 of storage, L10 demonstrated the lowest $(P<0.05)$ R630/580 values, whereas at days 30 and 50 similar results were obtained for L5 and L10 $(P>0.05)$. In addition, NT, L5 and L10 demonstrated decrease $(P<0.05)$ of R630/580 values during storage. 
Table 2 Means of $\mathrm{pH}$ and instrumental color parameters values on Longissimus dorsi steaks treated with lactic acid storage at $10^{\circ} \mathrm{C}$ during 50 days.

\begin{tabular}{|c|c|c|c|c|c|}
\hline \multirow{2}{*}{ Treatment* } & \multicolumn{4}{|c|}{ Days of storage } & \multirow[b]{2}{*}{ SEN } \\
\hline & $\mathbf{0}$ & 15 & 30 & 50 & \\
\hline \multicolumn{6}{|l|}{ pH } \\
\hline NT & $5.38^{\mathrm{aBC}}$ & $5.33^{\mathrm{aC}}$ & $5.50^{\mathrm{aAB}}$ & $5.63^{\mathrm{aA}}$ & 0.00 \\
\hline L5 & $4.46^{\mathrm{bC}}$ & $4.84^{\mathrm{bB}}$ & $5.26^{\mathrm{bA}}$ & $5.37^{\mathrm{bA}}$ & 0.01 \\
\hline L10 & $4.05^{\mathrm{cC}}$ & $4.66^{\mathrm{cB}}$ & $5.19^{\mathrm{bA}}$ & $5.21^{\mathrm{bA}}$ & 0.01 \\
\hline SEM & 0.01 & 0.00 & 0.01 & 0.01 & \\
\hline \multicolumn{6}{|l|}{$L^{*}$ (lightness) } \\
\hline NT & $38.34^{\mathrm{aA}}$ & $37.76^{\mathrm{aA}}$ & $38.25^{\mathrm{aA}}$ & $37.83^{\mathrm{aA}}$ & 1.89 \\
\hline L5 & $40.97^{\mathrm{aA}}$ & $37.12^{\mathrm{aB}}$ & $36.83^{\mathrm{aB}}$ & $35.01^{\mathrm{aB}}$ & 1.14 \\
\hline L10 & $38.73^{\mathrm{aA}}$ & $29.72^{\mathrm{bB}}$ & $30.19^{\mathrm{bB}}$ & $30.00^{\mathrm{bB}}$ & 1.04 \\
\hline SEM & 1.60 & 0.84 & 1.39 & 1.60 & \\
\hline \multicolumn{6}{|l|}{$a^{*}$ (redness) } \\
\hline NT & $22.09^{\mathrm{aA}}$ & $21.32^{\mathrm{aA}}$ & $21.22^{\mathrm{aA}}$ & $21.85^{\mathrm{aA}}$ & 0.16 \\
\hline L5 & $20.77^{\mathrm{bA}}$ & $14.19^{\mathrm{bB}}$ & $13.27^{\mathrm{bB}}$ & $13.17^{\mathrm{bB}}$ & 0.44 \\
\hline L10 & $16.10^{\mathrm{cA}}$ & $11.43^{\mathrm{cB}}$ & $11.06^{\mathrm{cB}}$ & $9.18^{\mathrm{cC}}$ & 0.40 \\
\hline SEM & 0.18 & 0.28 & 0.34 & 0.54 & \\
\hline \multicolumn{6}{|c|}{$\boldsymbol{b}^{*}$ (yellowness) } \\
\hline NT & $14.83^{\mathrm{bA}}$ & $13.73^{\mathrm{aAB}}$ & $13.67^{\mathrm{aB}}$ & $13.83^{\mathrm{aAB}}$ & 0.18 \\
\hline L5 & $15.79^{\mathrm{aA}}$ & $14.22^{\mathrm{aB}}$ & $13.21^{\mathrm{aB}}$ & $12.94^{\mathrm{aB}}$ & 0.27 \\
\hline L10 & $15.81^{\mathrm{aA}}$ & $9.76^{\mathrm{bB}}$ & $9.81^{\mathrm{bB}}$ & $7.84^{\mathrm{bC}}$ & 0.47 \\
\hline SEM & 0.12 & 0.13 & 0.49 & 0.49 & \\
\hline \multicolumn{6}{|c|}{$\begin{array}{l}\mathbf{R 6 3 0 / 5 8 0} \text { (ratio } \\
\text { of reflectance) }\end{array}$} \\
\hline NT & $4.48^{\mathrm{aA}}$ & $4.22^{\mathrm{aAB}}$ & $4.18^{\mathrm{aAB}}$ & $4.08^{\mathrm{aB}}$ & 0.02 \\
\hline L5 & $3.22^{\mathrm{bA}}$ & $1.76^{\mathrm{bB}}$ & $1.53^{\text {ьв }}$ & $1.53^{\mathrm{bB}}$ & 0.04 \\
\hline L10 & $1.82^{\mathrm{cA}}$ & $1.47^{\mathrm{cB}}$ & $1.41^{\mathrm{bBC}}$ & $1.34^{\mathrm{bC}}$ & 0.00 \\
\hline SEM & 0.05 & 0.00 & 0.00 & 0.02 & \\
\hline
\end{tabular}

Legend: ${ }^{a-c}$ Means in a column without common superscripts within a attribute are differen $(P<0.05)$.

${ }_{A}-\mathrm{C}$ Means in a row without common superscripts are different $(P<0.05)$.

* NT $=$ Non-treated samples, L5= samples treated with $0.56 \mathrm{M}(5 \%, \mathrm{v} / \mathrm{v})$ LA solution, and $\mathrm{L} 10=$ samples treated with $1.13 \mathrm{M}(10 \%$, v/v) LA solution.

$S E M=$ standard error of the mean.

\section{DISCUSSION}

The reduction of bacterial count in samples treated with LA solution is probably due to lactate anion accumulation (Van Immerseel $\boldsymbol{e t}$ al., 2006) which promoting membrane damage, ATP depletion, and disrupting nutrient transport (Cherrington et al., 1991). In addition, weak organic acids such as LA are considered lipophilic and capable of passing through cellular membrane, acidifying the bacterial cytoplasm, affecting homeostasis and influencing E. coli O157:H7 and TAMB growth (John et al., 2005).

In agreement with present results, Shrestha and Min (2006) reported a concentration-dependent pattern on TAMB reduction from the $4^{\text {th }}$ day of storage on fresh pork ham treated with solutions of LA at $1 \%$, up to $6 \%(\mathrm{v} / \mathrm{v})$. In partial agreement with present results, Zeitoun and Debevere (1992) observed that TAMB and Enterobacteriaceae counts remained constant in fresh chicken legs treated with lactic acid at $5 \%(\mathrm{v} / \mathrm{v})$ and $10 \%(\mathrm{v} / \mathrm{v})$ during at least 14 days of storage. On the other hand, Harris et al. (2012) observed a reduction of $0.8 \mathrm{log}$ $\mathrm{CFU} / \mathrm{g}$ on E. coli $\mathrm{O} 157: \mathrm{H} 7$ and TAMB counts in ground beef treated with lactic acid at $5 \%(\mathrm{v} / \mathrm{v})$ on day 0 . In addition, Pittman et al. (2012) reported E. coli O157:H7 reduction of $1.6 \mathrm{log} \mathrm{CFU} / \mathrm{g}$ on beef carcasses after $24 \mathrm{~h}$ of decontamination using 5\% (v/v) LA. Furthermore, Mahmoud (2014) observed reductions of 2.8 and $3.4 \mathrm{log} \mathrm{CFU} / \mathrm{g}$ of gram negative bacteria in inoculated oysters treated with LA of $0.5 \mathrm{M}$ and $1.1 \mathrm{M}$ immediately after LA application, contrasting with our results. These contrasts could be attributed to differences on LA application methods and type of matrix.

In relation to $\mathrm{pH}$ values, the LA decreased them immediately after application, probably due to a proton imbalance in meat muscle caused by LA solutions (Goli et al., 2011). Our results are in agreement with Naveena et al. (2006), which observed a decrease in $\mathrm{pH}$ values in buffalo meat treated with $2 \%(\mathrm{v} / \mathrm{v})$ of lactic acid, and with Shrestha and Min (2006) and Grajales-Lagunes et al. (2012) which treated pork meat with LA solutions ranging from $1 \%$ to $6 \%(\mathrm{v} / \mathrm{v})$ at the beginning of the storage period. Moreover, the increase pattern in $\mathrm{pH}$ values observed during storage can be attributed to amino acids decarboxylation in response to an acid stress (Halász et al., 1994). The decarboxylation is a cell mechanism to maintain the homeostasis, and the loss of a carboxylic group results in the formation of basic molecules, such as amines, that increases the $\mathrm{pH}$ of samples (Pereira et al., 2009).

Regarding surface color stability, $L^{*}$ values decrease during storage on L5 and L10 can be attribute to denaturation of myofibrillar proteins promoted by LA application affecting the water-holding capacity. The water dispersed among the muscle fibers may influence meat surface reflectance (Aktaş and Kaya, 2001) A decrease in $L^{*}$ values was also observed in fresh pork ham treated with solutions of LA during storage (Shrestha and Min, 2006).

Lactic acid affected $a^{*}$ values probably due to heme pigment oxidation induced by $\mathrm{pH}$ shift (Hunt et al., 1999; Pipek et $\boldsymbol{a l}$., 2005). The change on $\mathrm{pH}$ leads to premature browning of beef as a consequence of MMb accumulation (Smulders and Greer, 1998). In addition, the decrease on $a^{*}$ values during storage can be explained by myoglobin oxidation, promoting a decrease in redness (Carlez $\boldsymbol{e t}$ al., 1995). Meat redness decrease was reported in Longissimus dorsi beef (Aktaş, and Kaya, 2001), beef carcasses, (Pipek et al., 2005), beef trimmings (Harris $\boldsymbol{e t}$ al., 2012) and pork ham (Shrestha and Min, 2006) treated with 1.5, 2.0, 5.0 and $6.0 \%(\mathrm{v} / \mathrm{v})$ of LA solutions during storage, respectively.

The acid treatment can also affect the perception of $b^{*}$ values (Friedrich $\boldsymbol{e t}$ al., 2008). LA application increase protein denaturation and exudate release, as function of $\mathrm{pH}$ drop, which potentially explains the variations observed on meat yellowness (Greer and Dilts, 1995). The decrease in $b^{*}$ values in beef carcasses treated with $2 \%(\mathrm{v} / \mathrm{v})$ LA solutions during storage was also previously observed (Pipek et al., 2005; Mohan et al., 2011)

Color stability can be estimated based on the ratio of reflectance at $630 \mathrm{~nm}$ to 580 $\mathrm{nm}$ (R630/580). High ratio values indicate greater redness reflected by the greater $\mathrm{OMb}$ than $\mathrm{MMb}$ content, and a ratio value of 1.0 represents a meat surface with essentially $100 \%$ of MMb (Strange $\boldsymbol{e t}$ al., 1974). In agreement with the present results, previous researches (Stivarius et al., 2002; Pipek et al., 2005; Mohan et al., 2011) observed a decrease in R630/580 values in beef treated with $2 \%(\mathrm{v} / \mathrm{v})$, $5 \%(\mathrm{v} / \mathrm{v})$ of LA, as well as organic acid solutions, respectively. In addition, a decrease in R630/580 values on Longissimus lumborum and Psoas major muscles was also observed due to storage period (Joseph et al., 2012).

\section{CONCLUSION}

LA solution at $1.13 \mathrm{M}(10 \%, \mathrm{v} / \mathrm{v})$ promotes an efficient control on inoculated $E$. coli $\mathrm{O} 157: \mathrm{H} 7$ vacuum packaged steaks during storage at $10^{\circ} \mathrm{C}$. In spite of the technological potential of LA decontamination for meat industry, this method promoted meat discoloration with a premature browning on Longissimus beef surface.

Acknowledgements: This study was supported by the National Council of Technological and Scientific Development (CNPq), grants 311361/2013-7, 400136/2014-7 and 151460/2014-0 as well as, Carlos Chagas Filho Research Foundation (FAPERJ) grants number E-26/111.578/2013 and E26/201.185/2014. A. P. A. A. Salim was supported by the National Council for Scientific and Technological Development (CNPq). The authors would like to acknowledge the Frigorífico Rio Doce S/A - FRISA for providing Longissimus dorsi samples.

\section{REFERENCES}

Aktaş, N., \& Kaya, M. (2001). The influence of marinating with weak organic acids and salts on the intramuscular connective tissue and sensory properties of beef. European Food Research and Technology, 213, 88-94. http://dx.doi.org/10.1007/s002170100329

Alegre, I., Abadias, M., Anguera, M., Oliveira, M., \& Viñas, I. (2010). Factors affecting growth of foodborne pathogens on minimally processed apples. Food Control, 27, 70-76. http://dx.doi.org/10.1016/j.fm.2009.08.005

Alexa, P., Konstantinova, L., \& Sramkova-Zajacova, Z. (2011). Faecal shedding of verotoxigenic Escherichia coli in cattle in the Czech Republic. Veterinary Medicine Czech, 56, 149-155.

AMSA. (2012). Meat color measurement guidelines. American Meat Science Association, Champaign, IL, USA.

Anderson, M. E., \& Marshall, R. T. (2007). Reducing microbial populations on beef tissues: concentration and temperature of lactic acid. Journal of Food Safety. 10, 181-190. http://dx.doi.org/10.1111/j.1745-4565.1989.tb00019.x

AOAC. (2012). Official methods of analysis of AOAC International. Gaithersburg (Md.): AOAC International.

APHA. (2001). Compendium of Methods for the Microbiological Examination of Foods. (4th Ed.) American Public Health Association, Washington, D.C.

Barkocy-Gallagher, G. A., Arthur, T. M., Rivera-Betancourt, M., Nou, X., 
Shackelford, S. D., Wheeler, T. L., \& Koohmaraie, M. (2003). Seasona prevalence of Shiga toxin-producing Escherichia coli, including O157:H7 and non-O157 serotypes, and Salmonella in commercial beef processing plants. Journal of Food Protection, 66, 1978-1986.

Bell, C. (2002). Approach to the control of entero-haemorrhagic Escherichia coli (EHEC). International Journal of Food Microbiology, 78, 197-216. http://dx.doi.org/10.1016/s0168-1605(02)00188-5

Blagojevic, B., Antic, D., Adzic, B., Tasic, T., Ikonic, P., \& Buncic, S. (2015). Decontamination of incoming beef trimmings with hot lactic acid solution to improve microbial safety of resulting dry fermented sausages - A pilot study. Food Control, 54, 144-149. https://doi.org/10.1016/j.foodcont.2015.01.047

Buncic, S., \& Sofos, J. (2012). Interventions to control Salmonella contamination during poultry, cattle and pig slaughter. Food Research International, 45, 641655. http://dx.doi.org/10.1016/j.foodres.2011.10.018

Callaway, T. R., Carr, M. A., Edrington, T. S., Anderson, R. C., \& Nisbet, D. J. (2009). Diet, Escherichia coli O157:H7, and cattle: a review after 10 years. Current Issues in Molecular Biology, 11, 67-79.

Canto, A. C. V. C. S., Suman, S. P., Nair, M. N., Li, S., Rentfrow, G., Beach, C. M., Silva, T. J. P., Wheeler, T. L., Shackelford, S. D., Grayson, A., Mckeith, R. O., \& King, D. A. (2015). Differential abundance of sarcoplasmic proteome explains animal effect on beef Longissimus lumborum color stability. Meat Science, 102, 90-98. http://dx.doi.org/10.1016/j.meatsci.2014.11.011

Caprioli, A., Morabito, S., Brugère, H., \& Oswald, E. (2005) Enterohaemorrhagic Escherichia coli: emerging issues on virulence and modes of transmission. Veterinary Research, 36, 289-311. http://dx.doi.org/10.1051/vetres:2005002

Carlez, A., Veciana-Nogues, T., \& Cheftel, J. C. (1995). Changes in colour and myoglobin of minced beef meat due to high pressure processing. Food Science and Technology, 28, 528-538. http://dx.doi.org/10.1006/fstl.1995.0088

Cherrington, C. A., Hinton, M., Mead, G. C., \& Chopra, I. (1991). Organic acids: chemistry, antibacterial activity and practical applications. Advances in Microbial Physiology, 32, 87-108. Organic acids: chemistry, antibacterial activity and practical applications. http://dx.doi.org/10.1016/s0065-2911(08)60006-5

Dorsa, W. J., Cutter, C. N., \& Siragusa, G. R. (1998). Long-term effect of alkaline, organic acid, or hot water washes on the microbial profile of refrigerated beef contaminated with bacterial pathogens after Washing. Journal of Food Protection, 61, 300-306.

Food and Drugs Administration. (2016). Microorganisms \& Microbial-Derived Ingredients Used in Food (Partial List). http:// http://www.fda.gov/Food/IngredientsPackagingLabeling/GRAS/Microorganisms MicrobialDerivedIngredients/default.htm

Friedrich, L., Siró, I., Dalmadi, I., Horváth, K., Agoston, R., \& Balla, C. (2008) Influence of various preservatives on the quality of minced beef under modified atmosphere at chilled storage. Meat Science, 79, 332-343. http://dx.doi.org/10.1016/j.meatsci.2007.10.012

Gobert, A. P., Vareille, M., Glasser, A.-L., Hindré, T., De Sablet, T., \& Martin, C. (2007). Shiga toxin produced by enterohemorrhagic Escherichia coli inhibits $\mathrm{PI} 3 \mathrm{~K} / \mathrm{NF}$-kappaB signaling pathway in globotriaosylceramide-3-negative human intestinal epithelial cells. The Journal of Immunology, 178, 8168-8174. http://dx.doi.org/10.4049/jimmunol.180.1.664-b

Goli, T., Bohuon, P., Ricci, J., Trystram, G., \& Collignan, A. (2011). Mass transfer dynamics during the acidic marination of turkey meat. Journal of Food Engineering, 104, 161-168. http://dx.doi.org/10.1016/j.jfoodeng.2010.12.010 Grajales-Lagunes, A., Rivera-Bautista, C., Ruiz-Cabrera, M., Gonzalez-Garcia, R., Ramirez-Telles, J., \& Abud-Archila, M. (2012). Effect of lactic acid on the meat quality properties and the taste of pork Serratus ventralis muscle. Agricultural and Food Science, 21, 171-181

Greer, G. G., \& Dilts, B. D. (1995). Lactic acid inhibition of the growth of spoilage bacteria and cold tolerant pathogens on pork. International Journal of Food Microbiology, 25, 141-151. http://dx.doi.org/10.1016/0168-1605(94)00088$\underline{\mathrm{n}}$

Halász, A., Baráth, A., Simon-Sarkadi, L., \& Holzapfel, W. (1994). Biogenic amines and their production by microorganisms in food. Trends in Food Science \&. Technology, 5, 42-49. https://doi.org/10.1016/0924-2244(94)90070-1

Han, J. H. (2014). A review of food packaging technologies and innovations. In J. H. Han. Innovations in food packaging. San Diego: Academic. https://doi.org/10.1016/b978-0-12-394601-0.00001-1

Harris, D., Brashears, M. M., Garmyn, A. J., Brooks, J. C., \& Miller, M. F (2012). Microbiological and organoleptic characteristics of beef trim and ground beef treated with acetic acid, lactic acid, acidified sodium chlorite, or sterile water in a simulated commercial processing environment to reduce Escherichia coli O157:H7 and Salmonella. Meat Science, 90, 783788. http://dx.doi.org/10.1016/j.meatsci.2011.11.014

Hosseini, S. E., \& Esfahani Mehr, A. (2015). The effect of meat marinating with lactic and citric acid on some physicochemical and electrophoretic pattern of beef burger. Iranian Journal of Veterinary Medicine, 9, 103-108.

Huang, Y., \& Chen, H. (2011). Effect of organic acids, hydrogen peroxide and mild heat on inactivation of Escherichia coli O157:H7 on baby spinach. Food Control, 22, 1178-1183. http://dx.doi.org/10.1016/j.foodcont.2011.01.012
Huang, L., \& Sheen, S. (2011). Quantitative analysis of vertical translocation and lateral cross-contamination of Escherichia coli O157:H7 during mechanical tenderization of beef. Journal of Food Safety, 31, 108114 https://doi.org/10.1111/j.1745-4565.2010.00273.x

Hunt, M. C., Sørheim, O., \& Slinde, E. (1999). Color and heat denaturation of myoglobin forms in ground beef. Journal of Food Science, 64, 847851. http://dx.doi.org/10.1111/j.1365-2621.1999.tb15925.x

Hwang, C-A., Sheen, S., Juneja, V., Hwang, T-C., Yin, C-F., \& Chang, N-Y. (2014). The influence of acid stress on the growth of Listeria monocytogenes and Escherichia coli $\mathrm{O} 157: \mathrm{H} 7$ on cooked ham. Food Control, 37, 245-250. http://dx.doi.org/10.1016/j.foodcont.2013.09.040

John, L., Cornforth, D., Carpenter, C. E., Sorheim, O., Pettee, B. C., \& Whittier, D. R. (2005). Color and thiobarbituric acid values of cooked top sirloin steaks packaged in modified atmospheres of $80 \%$ oxygen, or $0.4 \%$ carbon monoxide, or

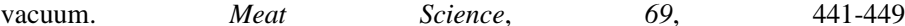
http://dx.doi.org/10.1016/j.meatsci.2004.08.013

Joseph, P., Suman, S. P., Rentfrow, G., Li, S., \& Beach, C. M. (2012) Proteomics of Muscle-Specific Beef Color Stability. Journal of Agricultural and Food Chemistry, 60, 3196-3203. http://dx.doi.org/10.1021/jf204188v

Karmali, M. A., Gannon, V., \& Sargeant, J. M. (2010). Verocytotoxin-producing Escherichia coli (VTEC). Veterinary Microbiology, 140, 360-370 http://dx.doi.org/10.1016/j.vetmic.2009.04.011

Kerry, J., O'grady, M., \& Hogan, S. (2006). Past, current and potential utilization of active and intelligent packaging systems for meat and muscle-based products: A review. Meat Science, 74, 113-130. http://dx.doi.org/10.1016/j.meatsci.2006.04.024

Lázaro, C. A., Conte-Júnior, C. A., Monteiro, M. L. G., Canto, A. C. V. C. S., Costa-Lima, B. R. C., Mano, S. B., \& Franco, R. M. (2014). Effects of ultraviolet light on biogenic amines and other quality indicators of chicken meat during refrigerated storage. Poultry Science, 93, 2304-2313. http://dx.doi.org/10.3382/ps.2013-03642

Leistner, L. (2004). Hurdle technology. In Juneja and Sofos. Control of foodborne microorganisms. New York. http://dx.doi.org/10.1016/b0-12-464970$\mathrm{x} / 00173-2$

Li, S., Kundu, D., \& Holley, R. A. (2015). Use of lactic acid with electron beam irradiation for control of Escherichia coli O157: H7, non-O157 VTEC E. coli, and Salmonella serovars on fresh and frozen beef. Food Microbiology, 46, 3439. https://doi.org/10.1016/j.fm.2014.06.018

Mahmoud, B. S. M. (2014). The efficacy of grape seed extract, citric acid and lactic acid on the inactivation of Vibrio parahaemolyticus in shucked oysters. Food Control, 41, 13-16. http://dx.doi.org/10.1016/j.foodcont.2013.12.027

Martinez, F. A. C., Balciunas, E. M., Salgado, J. M., Domínguez González, J. M., Converti, A., \& Oliveira, R. P. S. (2013). Lactic acid

properties, applications and production: A review. Trends in Food Science and Technology, 30, 70-83.

Meng, J., Feng, P., \& Doyle, P. (2001). Pathogenic Escherichia coli. In F. P. Downes, K. Ito. Compendium of methods for the microbiological examination of foods. Washington, D.C. http://dx.doi.org/10.2105/9780875531755ch35

Mohan, A., Pohlman, F. W., \& Mcdaniel, J. A. (2011). The impact of peroxyacetic acid, octanoic acid, malic acid, and potassium lactate as antimicrobial interventions on instrumental color characteristics of beef trimmings. AAES Research Series, 597, 116-119.

Muchenje, V., Dzama, K., Chimonyo, M., Strydom, P. E., Hugo, A., \& Raats, J. G. (2009). Some biochemical aspects pertaining to beef eating quality and consumer health: A review. Food Chemistry, 112, 279 -289. https://doi.org/10.1016/j.foodchem.2008.05.103

Naveena, B. M., Muthukumar, M., Sen, A. R., Babji, Y., \& Murthy, T. R. K. (2006). Improvement of shelf-life of buffalo meat using lactic acid, clove oil and vitamin C during retail display. Meat Science, 74, 409-415. http://dx.doi.org/10.1016/j.meatsci.2006.04.020

Pereira, C. I., Matos, D., Romão, M. V. S., \& Barreto Crespo, M. T. (2009). Dual role for the tyrosine decarboxylation pathway in Enterococcus faecium E17: response to an acid challenge and generation of a proton motive force. Applied $\begin{array}{llll}\text { and. Environmental } & \text { Microbiology, } & \text { 35, }\end{array}$ https://doi.org/10.1128/aem.01958-08

Pipek, P., Šikulová, M., Jeleníková, J., \& Izumimoto, M. (2005). Colour changes after carcasses decontamination by steam and lactic acid. Meat Science, 69, 673680. http://dx.doi.org/10.1016/j.meatsci.2004.10.018

Pittman, C. I., Geornaras, I., Woerner, D. R., Nightingale, K. K., Sofos, J. N. Goodridge, L., \& Belk, K. E. (2012). Evaluation of lactic acid as an initial and secondary subprimal intervention for Escherichia coli O157:H7, non-O157 Shiga toxin-producing $E$. coli, and a nonpathogenic $E$. coli surrogate for E. coli O157:H7. Journal of Food Protection, 75, 17011708. http://dx.doi.org/10.4315/0362-028x.jpp-11-520

Ricke, S. C. (2003). Perspectives on the use of organic acids and short chain fatty acids as antimicrobials. Poultry Science, 82, 632-639. http://dx.doi.org/10.1093/ps/82.4.632

Skandamis, P. N., Nychas, G-J., \& Sofos, J. N. (2010). Meat decontamination. Ames, IA, Blackwell Publishing. 
Scallan, E., Hoekstra, R. M., Angulo, F. J., Tauxe, R. V., Widdowson, M-A., Roy, S. L., \& Griffin, P. M. (2011). Foodborne illness acquired in the United States - major pathogens. Emerging Infectious Diseases Journal, 17, 7-15. http://dx.doi.org/10.3201/eid1701.p11101

Shrestha, S., \& Min, Z. (2006). Effect of lactic acid pretreatment on the quality of fresh pork packed in modified atmosphere. Journal of Food Engineering, 72, 254-260. http://dx.doi.org/10.1016/j.jfoodeng.2004.12.004

Smith, G. C., Belk, K. E., Sofos, J. N., Tatum, J. D., \& Williams, S. N. (2000). Economic implications of improved color stability in beef. In E. A. Decker, C. Faustman, \& C. J. Lopez-Bote (Eds.), Antioxidants in Muscle Foods: Nutritional Strategies to Improve Quality. New York: Wiley Interscience.

Siragusa, G. R. (1995). The effectiveness of carcass decontamination systems for controlling the presence of pathogens on the surfaces of meat animal carcasses. Journal of Food Safety, 15, 229-238. http://dx.doi.org/10.1111/j.17454565.1995.tb00135.x

Smulders, F. J. M., \& Greer, G. G. (1998). Integrating microbial decontamination with organic acids in HACCP programmes for muscle foods: prospects and controversies. International Journal of Food Microbiology, 44, 149-169. http://dx.doi.org/10.1016/s0168-1605(98)00123-8

Stivarius, M. R., Pohlman, F. W., Mcelyea, K. S., \& Waldroup, A. L. (2002) Effects of hot water and lactic acid treatment of beef trimmings prior to grinding on microbial, instrumental color and sensory properties of ground beef during display. Meat Science, 60, 327-334. http://dx.doi.org/10.1016/s03091740(01)00127-9

Strange, E. D., Benedict, R. C., Gugger, R. E., Metzger, V. G., \& Swift, C. E. (1974). Simplified methodology for measuring meat color. Journal of Food Science, 39, 988-992. http://dx.doi.org/10.1111/j.1365-2621.1974.tb07293.x

Suman, S. P., Faustman, C., Stamer, S. L., \& Liebler. D. C. (2007). Proteomics of lipid oxidation-induced oxidation in porcine and bovine oxymyoglobins. Proteomics, 7, 628-640. http://dx.doi.org/10.1002/pmic.200600313

Suman, S. P., Mancini, R. A., Joseph, P., Ramanathan, R., Konda, M. K. R., Dady, G., \& López-López, I. (2010). Color-stabilizing effect of lactate on ground beef is packaging-dependent. Meat Science, 84, 329-333. http://dx.doi.org/10.1016/j.meatsci.2009.08.051

Suman, S. P., \& Joseph, P. (2013). Myoglobin chemistry and meat color. Annual Review of Food Science and Technology, 4, 79-99. http://dx.doi.org/10.1146/annurev-food-030212-182623

Van Immerseel, F., Russell, J. B., Flythe, M. D., Gantois, I., Timbermont, L., Pasmans, F., Haesebrouck, F., \& Ducatelle, R. (2006). The use of organic acids to combat Salmonella in poultry: a mechanistic explanation of the efficacy. Avian Pathology, 35, 182-188 http://dx.doi.org/10.1080/03079450600711045

Youssef, M., Yang, X., Badoni, M., \& Gill, C. (2012). Effects of spray volume, type of surface tissue and inoculum level on the survival of Escherichia coli on beef sprayed with 5\% lactic acid. Food Control, 25, 717-722. https://doi.org/10.1016/i.foodcont.2011.12.021

Youssef, M. K., Yang, X., Badoni, M., \& Gill, C. O. (2013). Survival of acidadapted Escherichia coli O157:H7 and not-adapted E. coli on beef treated with $2 \%$ or 5\% lactic acid. Food Control, 34, 13-18. http://dx.doi.org/10.1016/j.foodcont.2013.03.037

Zeitoun, A. A. M., \& Debevere, J. M. (1992). Decontamination with lactic $\mathrm{acid} /$ sodium lactate buffer in combination with modified atmosphere packaging effects on the shelf life of fresh poultry. International Journal of Food Microbiology, 16, 89-98. http://dx.doi.org/10.1016/0168-1605(92)90001-j

Zhou, G. H., Xu, X. L., Liu, Y. (2010). Preservation technologies for fresh meat - A review. Meat Science, 86,119-128. https://doi.org/10.1016/j.meatsci.2010.04.033 